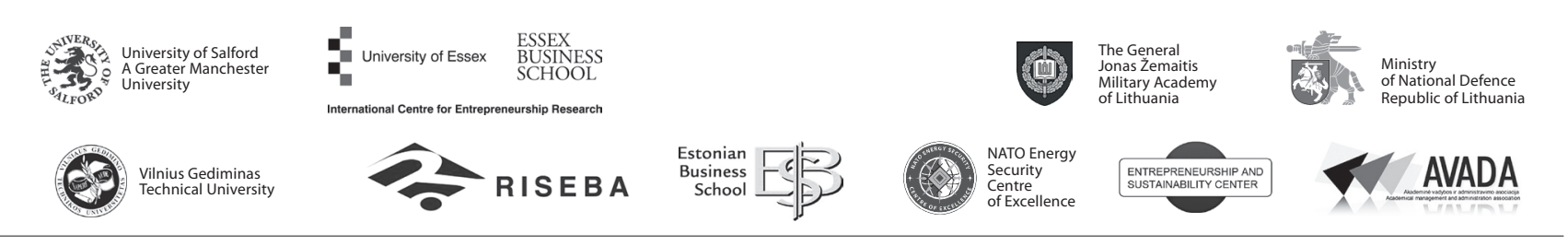

\author{
JOURNAL OF SECURITY AND SUSTAINABILITY ISSUES \\ ISSN 2029-7017 print/ISSN 2029-7025 online \\ 2018 March Volume 7 Number 3 \\ https://doi.org/10.9770/jssi.2018.7.3(3)
}

\title{
PROTECTION OF THE STATE AND SOCIETY: PUBLIC ADMINISTRATION AND PUBLIC (STATE) SERVICE
}

\author{
Jozef Kuril \\ School of Economics and Management in Public Administration in Bratislava, \\ Furdekova 16, 85104 Bratislava, Slovak Republic \\ E-mail: jozef.kuril@vsemvs.sk
}

Received 18 April 2017; accepted 19 January 2018

\begin{abstract}
Public administration in the conditions of the Slovak Republic contributes to a great extent to ensuring the internal and external security of the state. In the following article, the author deals with the relationship between public administration and public service as terms closely related. Author takes the view, that the basic characteristic of the concept of public service is based on its formal criterion, from work to the benefit of a legal person governed by public law (state, municipality, public corporation). He submits that a civil servant may be considered to be any employee employed by a legal person governed by public law as a civil servant only as an employee employed by the State. The concept of public service has the character of a complex legal institution intervening in several sectors of our rule of law (constitutional law, administrative law, labour law).
\end{abstract}

Keywords: internal protection of the state and society, state security, public administration, state administration, public service, state service

\section{JEL Classification: K 31, H 12, H 56, K 14}

Reference to this paper should be made as follows: Kuril, J. 2018. Protection of the state and society: public administration and public (state) service, Journal of Security and Sustainability Issues 7(3): 409-416.

https://doi.org/10.9770/jssi.2018.7.3(3)

\section{Introduction}

In this article, we apply a systemic approach to the addressed issue, mainly by using a method involving analysis and synthesis as general methods of scientific discovery. From other methods of scientific research, we apply logical methods of deduction and induction accordingly, as well as methods of comparison, observation, and abstract examination. The use of these methods leads to a deeper understanding of the particular issue. It also makes it possible to get to its core, as well as in relation to other subjects or phenomena.

Public administration in the conditions of the Slovak Republic contributes to a great extent to ensuring the internal and external security of the state, the protection of public order, as well as the fulfilment of important and irreplaceable crisis management tasks. The Slovak Armed Forces mainly play a key role in the defence strategy of the Slovak Republic, and the Slovak Police play a crucial role in ensuring the internal security and protection of public order. The Civil Defence Service, Fire Brigade and Rescue Service, Slovak Railway Police, Slovak Prison Service and Judicial Guards, and other bodies of public administration also play important roles in the internal and external security of the state. They represent a category of public services provided by 
public bodies for the benefit of society. Their functioning peculiarities are widely discussed in contemporary literature (Kordík, Kurilovská 2017; Luzgina 2017; Šišulák 2017; Limba et al. 2017; Tumalavičius, Šakočius 2017). These are sui generis public services (Siller, Cibák 2016; Kabát et al. 2016).

\section{Public Administration and State Administration}

In the legal system of the Slovak Republic, the terms "public administration" and "public service" are important legal institutes that are legally regulated, and through which the Slovak Republic, as a state, ensures fulfilment of various tasks and roles necessary for its functioning. In the current conditions of the Slovak Republic as a democratic state, the concept of public administration and public service is based on principles different from before November 1989, and it must also correspond to and be comparable with modern legal regulations in other democratic countries, particularly in the EU, in this respect.

In the substantial (functioning) concept, public administration is understood as a certain kind of activity (actual performance of administration). This concept is understood to mean activity of a state as a basic public law entity, which is carried out via its bodies, as execution of activities of other public law entities, which has a basis in administration of public affairs and which is carried out as an expression of executive power in the state. In terms of substance, it is focused on securing of public affairs as well as public services and on power protection of public interests In the formal (institutional) sense, we can understand public administration as a set of public authorities, and in this context emphasis is placed on institutions, which have the power and authority to handle public tasks, unless such power and authority is assigned to the Parliament or courts, or in other words it involves activities of authorities referred to as administrative authorities.(Škultéty, Štangová 2014; Štangová et al. 2015).

Public administration enforces legislation via its executive bodies, unlike legislature, where law making bodies create and pass legislation. So, while legislatures make laws, public administration enforces them. Public administration differs from courts in terms of function and organisation. From a function point of view, the judicial system represents "discoveries of law" while public administration represents the enforcement of public interests within the bounds of the law. In terms of organisation, the judicial system works through mutually equal bodies, while the system of public administrative bodies is strictly controlled by relationships of subordination and superiority. The judicial system can be characterised as coordination, the system of public administrative bodies as subordination.

Public administration as administration of public affairs is administration in the public interest, and the bodies executing it as a legally imposed duty based on their status as public law entities.

Under certain circumstances, in the public administration also private law entities can participate, mainly when public administrative bodies order performance of public services, which otherwise they would have to carry out on their own, from a private law entity. The activities of these entities in this case are no longer private law activities in their context, but become activities carried out in the public interest. However, such performance of public administration is only possible if the position of the public law entity can be substituted and if this is not excluded by the nature of the matter.

From the point of view of state activity, public administration can be defined negatively, as state activity which the state performs in addition to legislative and judicial activity. In terms of the activity of other public law entities other than the state, public administration is non-state activity of an executive nature, which is intended to ensure the performance of state administration. These additional public law entities represent independent public law corporations, which derive their subjectivity in a certain sense from the state and are also approved by it. Such corporations perform public administration in their own name and under their own authority, and the administration that they carry out is basically a form of self-governing.

The activity of the state in the area of administration is also focused on direct administration of state matters, for 
which the state has delegated its powers and authority as a result of social effectiveness and in accordance with the interests of all elements of the administrative complex as a sphere of its own exclusive interest as well as creation of regulations that limit the activity of the entire administrative complex. The administrative complex is designed vertically and horizontally. Its horizontal form involves the category of a legal entity with public law status, and as a result of its application two basic administrative sub-systems are formed. They are state administration and non-state administration.

Functioning of public administration as administration of public affairs is carried out as a manifestation of executive and leadership activities (power) in the state. The social relationships that are formed and implemented in relation to performance of state administration are determined by the administrative legal method of legal regulation. This is apparent from the basis of law, which regulates administrative legal relationships and which in its very basis is included in public law. Public law regulates relationships between entities, which are not equal to each other (the relationship of subordination and superiority) and ensures protection of public interests. (Hendrych et al. 2012; Škultéty, Kaššák 2014).

The use of the term "public administration" is closely related to the term "public (state) service". (Kuril 2006). From an analysis of the term "public administration" and mainly from its functional limitation, it is implied that realisation of public administration represents a specific type of public service, and so the terms "public administration" and "public service" in this context are terms closely related to each other, to a certain extent almost identical. More dimensions of the term limitation of "public service" are created by its combination with a personal element, a public employee.

Organisational and functional narrow definition of public administration (public service) enables us in connection with the personal element to register multiple changed forms of interconnection.

Public administration - public service - public employee (broadest expression);

State administration - state service - state employee (state official);

Public administration (without state administration) - public service (without state service) - public employee (without a state employee), i.e. narrower expression.

The specified interconnections prompt multiple questions, in relation to which it is necessary to adopt a qualified position. This mainly involves a search for an answer to the question of narrower definition:

of the term public service and state service in connection with its personal element;

of personal substrate having an effect in public and state service and its legal position.

Findings from domestic and foreign professional literature indicate the complexity of clear definition of these terms and indicated relationships. This situation only confirms the fact that determination of public service and/ or state service entities (personnel scope) and activities that these entities carry out within the scope of such service (substantial scope) are a traditional feature of national legislation based on traditions, organisation of public administration, and last but not least, also from financial means of ensuring performance of public administration by entities that ensure it, through public employees.

Public service is very closely linked to the society that sets it up and needs it "in order to be able to function". This applies for states and their parts to the same extent as for the states participating in international organisations. The existential significance and functioning of public service for society enables this service to be assessed as a sign of quality of a certain society, in both a positive and negative sense. The term "public service" can be characterised by substantial and formal features. However, in the legislation of countries applying the institutes of public service, a formal criterion dominates. The concept of public service is not so much about the type of activity that will be performed, and not about what activity is involved, or whether or not it is in the public interest, but about whether the activity of the persons performing it represents service (work performance) for the benefit of a legal entity governed by public law (formal theory). 
The narrower definition of public service in a substantial and formal sense basically copies the narrower definition of public administration in its organisational and functional sense in our theory of public administration. In this context, public service represents:

- activities related to performance of public administration, and/or

- Identification of groups of people in relationships with a legal entity governed by public law.

This dimension of public service requires clarification (analysis) of interconnections mentioned above.

\section{3. Relationship Between Public Administration and Public Service}

In the broadest sense (content and scope), the first level of relationship is represented by public administration (public service) and personnel element implementing it. If we focus on the substantial and formal theory of public service, then we can regard as a public service activity the activity carried out in public administration, in its entire sense of comprehension, i.e. in state administration, local government and public law corporations (and the group of people who carry out such service (work performance) for the benefit of a legal entity governed by public law.

The second level of connection represents the link between state administration - state service and the personnel element implementing it. State administration and state service represent a narrower concept than the terms public administration and public service. State administration represents administration of state affairs as opposed to non-state affairs (local government, public law corporations). It is usually associated with the implementation of ranking authority (activities) of the state. To an extent similar to narrower definition of public administration (public service) in the broadest sense, it also applies that we regard as state service the activity carried out in state administration as well as the group of persons carrying out such service (work performance) not for the benefit of any legal entity governed by public law, but only for the benefit of the state and in relation to the state.

The third level of the relationship includes the exercise of public administration and public service in connection with the personnel element, disregarding both state administration and state service. This public service in the narrower sense relates to activities performed in public administration with exclusion of state administration, and involves mainly ensuring the matters which represent public interest, including matters of local governments. Full expression of the personnel element means in the first case a public employee in the broadest sense and in the second case a state employee and in the third case a public employee in the narrower sense.

The specified options and definitions of the terms only represent basic modifications that can occur in public (state) service. As we have already indicated, various overlapping of functional (substantial) and organizational (formal) criteria can result in various modifications in the term public (state) service and in its personnel and substantial definition. There are also others approach to the above characteristics of public service. For example, Prusák States that "public service expresses legal status, which means the legal situations of employees of public (state) administration and/or other bodies (judges)". The institution of public service is a method of professionalization of public administration and in particular state administration which is differentiated from politicization of state administration. (Prusák 2007).

Differentiation of public service needs to be viewed in the context of affiliation to institutions and performance of work positions related to fulfilment of public tasks (public interests). "The special nature of an employer as primary carrier of public administration, the subject of services, co-activity during performance of public administration, the need for narrow organic involvement of an employee in the organism of the employer" have all been signs which according to the Supreme Administrative Court prompted the need for regulation other than "the regulations of general civil law regarding service contracts" and gave rise to the independent "public law institute". (NS 1920) 
The level of autonomy of other employer's entities, mainly territorial public law corporations, which together with part of state power also take on certain other characteristics, determines whether the status of employees of local government is at least generally regulated together with the situations of state employees or is regulated by special laws.

Other criteria such as participation in ensuring public tasks, public services, public interests etc. have begun, over time in a larger number of countries, to seem too broad and do not provide sufficient justification for the specific legal status of the extensive social strata of public employees (including employees in public services and/or public undertakings). The performance of public tasks nowadays is often delegated to entities in the public or private sector (or of a mixed nature) with a certain degree of autonomy in relation to which the state (a public law corporation) maintains certain control and financial ties. Also, within the scope of administrative bodies the actual need for a specific legal regime is related to the performance of state administration in its own sense ("proper public administration"), and it does not apply to auxiliary, service or technical work.

The often used practical basis for narrower definition of public service is remuneration of employees from the public budget. This is the way how the particular issue is also approached by recommendations of the Council of Europe. Within the scope of this narrower definition, groups of employees are defined the situation of which more or less deviates from the general regulation of employment (labour law) relationships.

It is true that in some countries contracted employees are subject to private law, opposed to the employees to whom public law applies. The court more or less states in the current practice of the member states, the said employees and contracted employees often carry out equal and/or similar roles. The fact whether the applied legislative provisions in domestic law are part of public or private law cannot, based on the firmly enshrined case-law of the European Court for Human Rights, be decisive alone, and in any case this would lead to unequal treatment with persons in state services performing equal roles. "Furthermore: "The court has expressed the opinion that is appropriate to adopt substantial (functional) criteria based on the nature of the functions and responsibilities of the employees. At state administration authorities, some work positions include fulfilment of general interest and/or participation in the execution of public powers, and therefore their holders have in their hands part of the sovereignty of the state which therefore has legitimate interest in requiring a special degree of trust and loyalty from these employees. (Kuril, Minčič 2015)

Several conclusions are apparent from what has been stated above for the narrower definition of public service:

- The determining factors for special usually public law regulation of public service include the participation in the execution of state power and the mandate to promote the public interest;

- For more detailed differentiation, a functional criterion is applied expressing the nature of a work duties and the nature and degree of responsibilities;

- the mentioned criteria have relevant validity, and therefore they cannot be considered an absolute measure requiring the selection of one system or another. In fact, even within individual states situations arise when equal or similar functions are performed both by contracted employees and employees appointed to state service.

In view of the current legal regulation and legal definition of work performance by employees of public authorities in this country, however, the issue of public service has attracted the attention of experts in labour law. In this context, it is considered appropriate to state that the labour law theory also includes a substantially similar specification of public service as in the theory of administrative law.

We are of the opinion that the fundamental characteristics of public service are based on its formal (institutional) criterion, i.e. work performance (service) for the state, municipality or other public law corporation, which means the performance of public administration for the benefit of a legal entity governed by public law. In this context, it is not important whether the employees perform public service in a public law or private law employment relationship. 
However, the characteristics of public service also include a substantial (functional) criterion, i.e. the nature of activities in public service. Nonetheless, this criterion is, in our opinion, only secondary and is only used when differentiating activities carried out in public administration. Based on this criterion, we distinguish the terms state service, public service in the narrower sense, general service etc.

The term public (state) service and the term legal situation of public (state) employees are very close, but not identical. In this context, we are of the opinion that titles (identifying descriptions) of legislation regulating the legal situation of public employees should not be "Public Service Act, State Service Act", but should rather read as follows "act concerning the legal status of civil servants, act concerning the legal status of public employees and/or employees in public (state) services, and/or act concerning state service and legal status (relationships) of civil servants (officers) etc.

The personal element gives a broader meaning to the term public service than has been stated in the previous sections.

\section{Public service as a legal institute}

The term public service as a legal institute has the nature of:

- A comprehensive legal institute comprising institutes of constitutional, administrative and labour law as well as other branches of law which relate to public (state) service within the scope of the application of their provisions; this involves mainly constitutional bases for the access to public office positions and/or authorities and administrative law aspects, the scope of activities performed by public (state) administration and labour law aspects pertaining to the legal regime of performance of activities comprising the scope of public (state) service.

- An institute of administrative law (which can involve the matter of consideration and/or general or specific parts) which defines such a substantive scope of activities and the group of persons and bodies that perform this activity (public, and/or state service), including their personnel status;

- An institute of labour law which determines the legal regime (legal relationships) of employees fulfilling tasks which fall within the scope of public (state) service comprehensively or partially (i.e. in combination with other branches of law, mainly administrative law). (Kuril 2006)

The concept of state and/or public service varies in various countries. It is distinguished mainly by a particular employing entity, as well as by services which it includes and by the number of employees that are considered to be state or public employees. These varying concepts are based on different definitions of state (public) service in constitutions, in political and social systems and in organizational standards of the state. In specialised literature the term state employees (as well as public employees) are most often defined based on the definition of the employing entity. The term public employers includes both state and public employees at the level of central government and local municipal governments regardless of whether they are included in one or more legal regimes or work in general administration or special agencies such as healthcare institutions, post offices, educational institutions, and in some cases transport or at least railways and in some cases police and security agencies.

These characteristics of the term public employee are also referred to in the 1978 Convention of the International Labour Organization No. 151 concerning Labour Relations in the Public Service. Articles 1 and 2 of the above Convention state that the term public employee means any person employed by a public authority and/ or legal entity governed by public law.

This definition of the term public employee corresponds to the formal and theoretical definition of public service. In this context it is possible to regard any employee who is employed by a legal entity governed by public law to be a public employee regardless of the legal regulation regime of regulation of employment relationships (private law or public law). 
Acceptance of substantial criterion (i.e. the nature of activity) has already been used in this document to distinguish public service, except for the broadest definition of this term, and the term state service and the term public service in the narrower sense. State service is performed by a state employee while public service (in the narrower sense) is performed by a public employee.

The scope of activities, and thereby also the group of persons (substantial and personnel application) through which the scope of state service is performed and/or form the scope of state service and thereby also public service, varies in different countries. State service is mainly performed by state employees (civil servants), and the basis for their legal relationship to the employer (state) tends to be public law state employment relationship (civil servant, service relationship) (sometimes also based on a public law contract).

It is an exclusive matter of each state what it considers to be the performance of state and/or public service and which employees will be considered state employees and which will be considered public employees. While in one country state school teachers will be, for example, considered civil servants, in another, they will be considered public employees not civil servants.

\section{Conclusion}

Under the substantial (functioning) concept, public administration means a certain type of activity (actual performance of administration). This concept is understood to mean activity of a state as a fundamental public law entity, but also activities of other public law entities, which has a basis in administration of public affairs and which is carried out as an expression of executive power in the state. Under the formal (institutional) concept, we understand public administration as a system of public authorities, involving the activities of authorities identified as administrative authorities.

However, public administration as administration of the state is not exclusively activity of state administration, but it also includes activity of non-state nature which of the executive character. Public administration consists of three constituent elements, in particular: State administration, local governments and public law corporations. It is apparent from the above that the term public administration is broader than the term state administration.

From the analysis of the term public administration, mainly from its functional definition, it is evident that, whereas the execution of public administration represents a specific public service, then the terms "public administration" and "public service" are similar to each other and overlap.

The term public service can be characterized using substantial and formal features (i.e. the definition of the term public service in its functional and institutional terms). From this point of view, public service represents, on one hand, activity relating to the performance of public administration and, on the other hand, identification of a group of persons with relationship to a legal entity governed by public law. We are of the opinion that the basic characteristics of the term public service are based on its formal criterion, i.e. from work performance (service) carried out for the benefit of a legal entity governed by public law (state, municipality, other public law corporation).

The term public service is broader than the term state service, whereas public service means activity carried out in public administration, in its broadest sense of comprehension, i.e. in state administration, local governments and public law corporations, as well as the group of people who carry out such service for the benefit of a legal entity governed by public law. While state service means activity carried out "only" in state administration, as well as a group of persons carrying out services "only for the benefit of and in relation to the state.

Employment relationships in public service and state service in the Slovak Republic in view of their unique and specific characteristics have their own autonomous legal regulation which is separated from general legal regulation of employment relationships established on the labour market. At the same time, the legislation 
regulating state service in the Slovak Republic is also differentiated internally and consist of a number of laws regulating the legal position of various categories of state employees. These include for example employees in state administration as well as police officers, professional soldiers, firemen, customs officers etc.

Any employee who is employed by a legal entity governed by public law may be considered a public employee, regardless of which legal regulation regime is applied. We regard as a state employee only an employee who is employed by a state, usually in a public law state employment relationship (service relationship) which can also be established by a public law contract.

The term public service as a legal institute represents a set of legal standards that regulate mutual and closely related social relationships in the field of organization and activities of public administration.

The term public service has the nature of a comprehensive legal institute crossing multiple branches of our legal system.

\section{References}

Hendrych, D. et al. 2012, Administrative Law, General Part, 8th Issue, Prague C. H. Beck 2012, ISBN 978-80-7179-254-3, p. 792

Kabát, L.; Filip, S.; Filipová, L. 2016 Safety measurement peculiarities in selected countries, Journal of security and sustainability issues 6(3): 343-356. http://dx.doi.org/10.9770/jssi.2017.6.3(2)

Kordík, M.; Kurilovská, L. 2017. Protection of the national financial system from the money laundering and terrorism financing, Entrepreneurship and Sustainability Issues 5(2): 243-262. https://doi.org/10.9770/jesi.2017.5.2(7)

Kuril, J. 2006. State Service, Bratislava, Academy of the Police Forces 2006, ISBN 80-8054-374-7, p. 47

Kuril, J. Minčič, V., 2015. Public Service in the Slovak Republic, Bratislava, VŠEMVS 2015, ISBN 978-80-89654-14-7, p.10

Kuril, J.; Minčič, V. 2015. Public Service in the Slovak Republic, Bratislava, VSEMVS 2015, ISBN 978-80-89654-14-7, p.29

Limba, T.; Agafonov, K.; Paukšte, L.; Damkus, M.; Plèta, T. 2017. Peculiarities of cyber security management in the process of internet voting implementation, Entrepreneurship and Sustainability Issues 5(2): 368-402. https://doi.org/10.9770/jesi.2017.5.2(15)

Luzgina, A. 2017. Problems of corruption and tax evasion in construction sector in Belarus, Entrepreneurship and Sustainability ISsues 5(2): 263-282. https://doi.org/10.9770/jesi.2017.5.2(8)

Prusák, J. 2007. Theory of Law, Bratislava VO PFUK 2007, ISBN 80-7160-094-6, p. 75

Siller, H.; Cibák, L. 2016. Korruption und ihre gesamtwirtschaftliche Bedeutung, in Kriminalistike - Osterreich [Corruption and its macroeconomic significance, in Kriminalistike - Austria] 1/2016, ISBN 978-3-783-084-71/2016, ISBN 978-3-783-084-7

Šišulák, S. 2017. Userfocus - tool for criminality control of social networks at both the local and international level, Entrepreneurship and Sustainability Issues 5(2): 297-314. https://doi.org/10.9770/jesi.2017.5.2(10)

Škultéty, P.; Kaššák, R. 2014. Administrative Substantive Law, Bratislava, Veda 2014, ISBN 978-80224-1376-3, p. 38

Štangová, N.; Víghová, A.; Múčka, M. 2015. Premises for applying of the process mapping in self-government in Slovakia, Journal of Central European Green Innovation 3 (4): 91-98 http://ageconsearch.umn.edu/record/229338/files/Stangova\%20et\%20al.pdf

Tumalavičius, V.; Šakočius, A. 2017. Ensuring public security in the field of traffic safety, Journal of Security and Sustainability Issues 7(2): 233-246. https://doi.org/10.9770/jssi.2017.7.2(5)

Jozef KURIL, prof. JUDr. CSc. is the Head of Security Management Department and teacher of the School of Economics and management in Public Administration in Bratislava. His text books, monographs and scientific papers deal with the Human Security, State Security, State Services. As former Rector of the Police Academy is succesfull leader and manager of many scientific projects. 